\title{
Development Student Worksheet in the Topic of Regular Circular Motion with Blended Learning based Edmodo as Learning Motivations for Student
}

\author{
Susilawati*, Eni Setyawati, and Ishafit \\ Program Studi Magister Pendidikan Fisika, Universitas Ahmad Dahlan \\ Street Parmuka No.42 Yogyakarta Indonesia \\ Email: *susiilawatii2009@gmail.com
}

\begin{abstract}
The research aims to develop learners ' worksheets on the subject of circular motion with the Edmodo based blended Learning as student motivation in learning physics. In the process of field testing, the study involved students of class $\mathrm{X}$ in vocational high school as research subjects. The model used is the ADDIE development model, which includes five stages: Analysis, Design, Development, Implementation, and Evaluation. To know the feasibility of media done validation. This validation is in the form of a poll with predefined criteria and indicators. From the development of student worksheet conducted an expert test of materials, media experts and users with a percentage of $79.68 \%, 77.27 \%$ and $83.62 \%$, respectively then the student worksheet with blended learning utilize Edmodo as the motivation to learn learners in the categorized worthy as a learning media.
\end{abstract}

Keywords: edmodo, blended learning, motivation, education

\section{Introduction}

The development of science and technology increasingly encourages efforts to improve the quality of education by utilizing technological outcomes in learning. Improving the quality of education in the learning process is not detached from the role of educators or teachers.

Student Worksheets or learners' Worksheets printed teaching materials in the form of sheets of paper containing material, summaries and instructional assignments to be performed by learners [1]. They create a friendly and attractive student worksheet, and there should be an innovation developed [2].

The educators must possess and develop the quality of ICT use capabilities and utilize it as a learning tool to create meaningful learning experiences, improve motivation and achievements. The utilization of diverse Internet and simulation technologies can help students reconstruct knowledge, and more accessible students observe events with remote instruments and establish Communication with educators all over the world [3].
To realize these skills or skills need to conduct learning that implements a Blended learning-based learning model. The blended learning method is the development of a conventional and face-to-face elearning model [4].

The blended learning method is a learning model that combines a variety of conveyance methods, educational models, learning styles, and a wide range of technology-based media. The blended learning model has several advantages, including the effectiveness of learning, learning, cost efficiency, and adaptation of learning style that is owned by the learners. Blended Learning Models help students learn independently.

Edmodo is a social networking website that is similar to Facebook that is used for the learning process to facilitate the learning process for educators, students and parents [5]. Edmodo can be used as a platform Learning communication to support learners ' learning The level of individuals, groups and levels of all classes, both inside and outside the classroom, which can be used throughout the formal and informal learning arrangements, enabling learners to collaborate, communicate, submit tasks with Upload and download files. Teachers can share notes with 
students, connect to useful websites, upload and download, provide reference learning resources for students, create an online quiz, news notifications and event agenda [6].

The subject of circular motion is physics-level learning material of SMK grade X. The subject selection of circular motion is irregular due to the irregular circular motion material having a concept that is difficult for learners to understand.

Many media can be used by teachers in the learning of physics so that learners are easier to understand and master the concept of the material learned. As one of the efforts to motivate learners in the learning of physics, the development and implementation of a physics learning model, especially on the subject of circular motion is irregular using media Edmodo.

Based on the description researchers interested in researching "the development student spreadsheets on in the topic of circular motion with Blended Learning in Edmodo as motivation for learning learners."

\section{Theory}

Learners ' Worksheets are sheets containing tasks that learners must work with to master the required competencies [7]. In the learning of physics, especially in circular motion material, it is necessary to use methods in the learning process to support the development of students ' worksheets.

The method used is blended learning that refers to the strategy of combining face to face learning and computer learning, both online and offline conducted through e-learning [8].

Edmodo is an application that resembles Facebook, but with a high educational value, it appeals to teachers and students [9]. Edmodo is a social media platform often depicted like Facebook for schools and can function more following the needs of teachers and learners [10].

Motivation plays a significant role in student academic work and achievements. In this reflected in the tasks undertaken by the students and in overcoming the obstacles, they face in the learning process [11]. High low motivation at the level of education affects students' success [12].

Regular circular Motion is the motion of an object on a circular trajectory that has a linear velocity $(v)$ fixed [13]. It also has a centripetal acceleration (leading to the centre of the circle) with the magnitude given by:

$$
a=\frac{v^{2}}{r}
$$

with $r$ is the radius of the circle $(m)$, can be written centripetal force as:

$$
F=m \frac{v^{2}}{r}
$$

With $F$, is a centripetal force $(N), \mathrm{V}$ is a linear speed $(\mathrm{m} / \mathrm{s}), m$ is a mass of objects $(\mathrm{kg})$. Physics at the motion of the corners $(\theta)$,

$$
\theta=\frac{s}{r}
$$

Period $(T)$ The time required by an item to move one round called a period,

$$
T=\frac{2 \pi}{\omega}
$$

with $T$ is a period (second), $\omega$ is the angular velocity $(\mathrm{rad} / \mathrm{s}), 2 \pi$ is an angular displacement for one round.

1. Linear speed and pace $(v)$

$$
v=\frac{2 \pi r}{T}
$$

Relationship linear velocity $(v)$ and angular velocity $(\omega)$

2. Linear speed and pace $(v)$

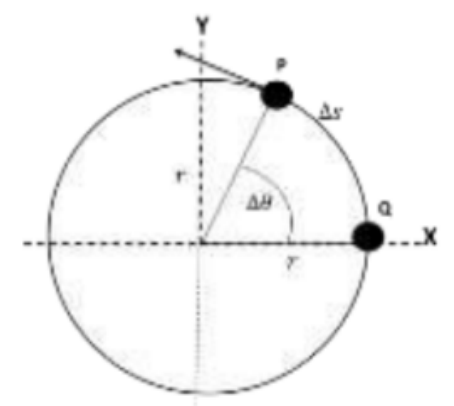

Figure 1. Linear velocity in circular motion [13]

In Figure 1 linear velocity in a circular motion with $v$ is speed $(m / s), r$ is the radius $(m), \omega$ is the angular velocity $(\mathrm{rad} / \mathrm{s})$ is obtained,

$$
v=r \omega
$$

\section{Methodology}

The types of research used are research and development, which is a method of research used to produce specific products and test the effectiveness of the product [14].

The development model in the study uses ADDIE's model of development, which is analysis, design, development, implementation, and Evaluation (evaluation) [15]. The development procedures in this study are as follows. 


\section{A. Stage Analysis}

Stage analysis is an early stage in the process of developing learning media. This stage is used by researchers to conduct a study of concepts or theories, and the student worksheet will be developed.

\section{B. Planning Phase of research}

At this stage, researchers devised the form of student worksheet on GMB material with mediaassisted Edmodo to produce a valid student worksheet.

\section{Stage of design development}

At this stage the researcher developed an initial product of EDMDO assisted by Edmodo media, developed student worksheet seen in Figure 2 containing: student worksheet summary, learning steps, core competencies and essential competencies, learning objectives, material consisting of regular circular motion material and additional material from Edmodo media, practice questions with answer keys, and bibliography.

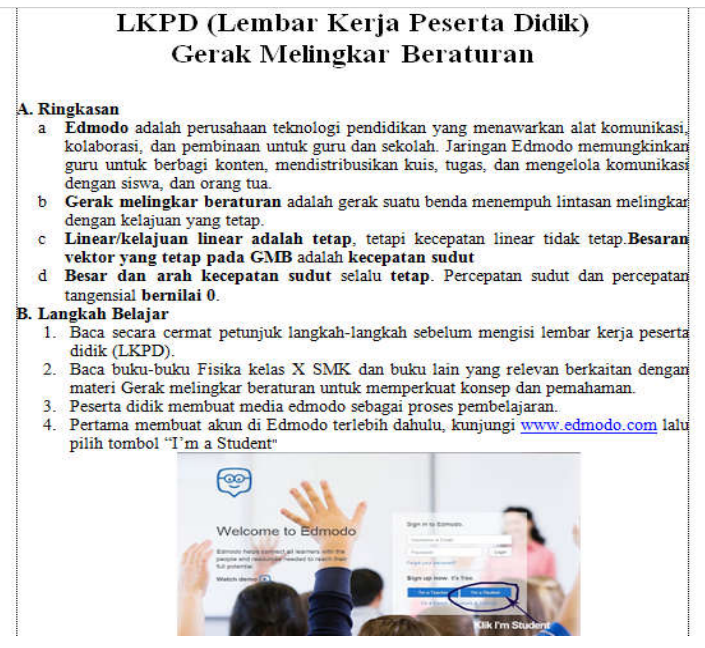

Figure 2. student worksheet design

\section{Stage of Implementation}

The assessment in the LKPD tested by the experts covering four aspects of content, conformity of presentation with a learning approach, linguistic, and technical requirements

\section{E. Stage of Evaluation}

The evaluation stage is the final stage of research. The achievement of research objectives measured from data obtained through a poll.

The research conducted at Vocational High school, Subjects in the study were material experts, media experts, as media validators, and students of vocational high school were students of X-class as users. The types of data collected on this research are quantitative data obtained through a poll as a research instrument.

$$
P=\frac{f}{N} \times 100 \%
$$

The measures used to provide quality criteria to developed products obtained from experts are: (1) Change the statement to score using the Likers scale [16]. (2) Calculating the values of all components with formulas according to is the number of frequencies, $f$ is the frequency of the respondent who gave the answer and $P$ is the percentage of respondents.

Tabel 1. Value Interval for media feasibility level [14]

\begin{tabular}{cc}
\hline Interval $(P)$ & Eligibility criteria \\
\hline $80 \%-100 \%$ & Very good \\
$66 \%-79 \%$ & Good \\
$56 \%-65 \%$ & Less good \\
$0 \%-55 \%$ & Not good \\
\hline
\end{tabular}

\section{Results and Discussion}

From the results of the analysis, testing of the program aims to determine media feasibility as a medium of physical learning in GMB material is reviewed from the aspects of content, presentation, language, and technical requirements. Overall based on the assessment of the validators of the expert media experts and students as users.

At the validation stage, as seen in the test bar diagram of the material expert tests in Figure 3. On the bar diagram, the results of the expert percentage of feasibility material $79.68 \%$. On the bar chart, the test results of the media expert in Figure 4 of the $77.27 \%$ feasibility percentage.

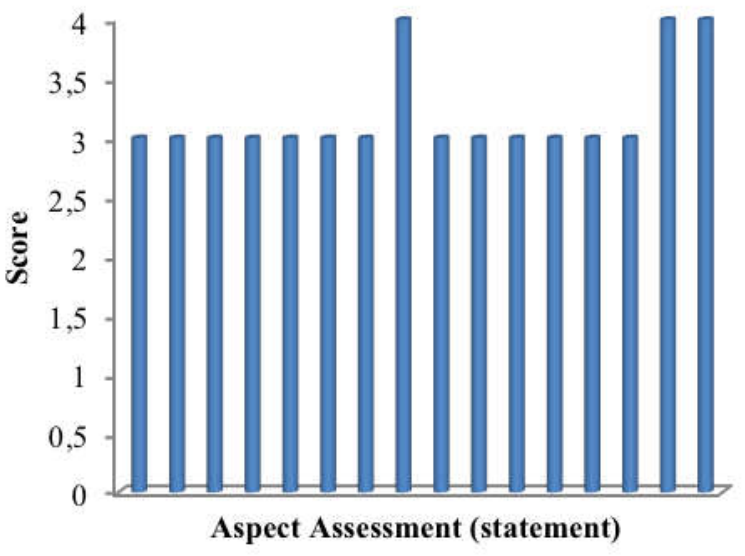

Figure 3. Bar chart of material expert test results 


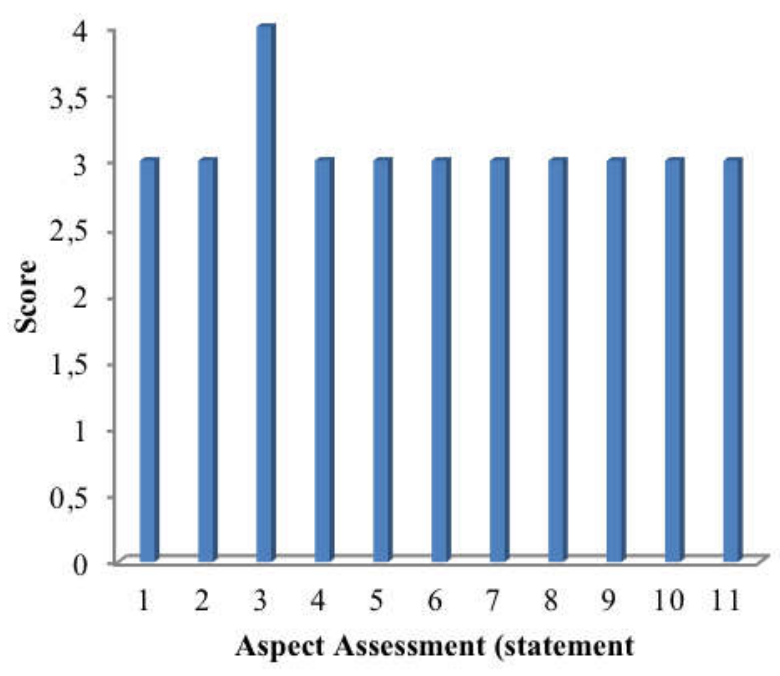

Figure 4. Bar Chart of media expert test results

The results of revisions and validations by experts a then tested. The results of the product trials in this study were the responses of the participants in the media Edmodo. Students ' responses or responses can be known by the way learners are asked to use LKPD with Edmodo, and then learners fill their responses to the polls provided.

Based on the results of the student's overall assessment, the average score of all $83.62 \%$ questions with the majority of student responses expressed strongly concur (SS) of Edmodo-based learning media as a participant motivation In the physics learning process presented in Figure 5.

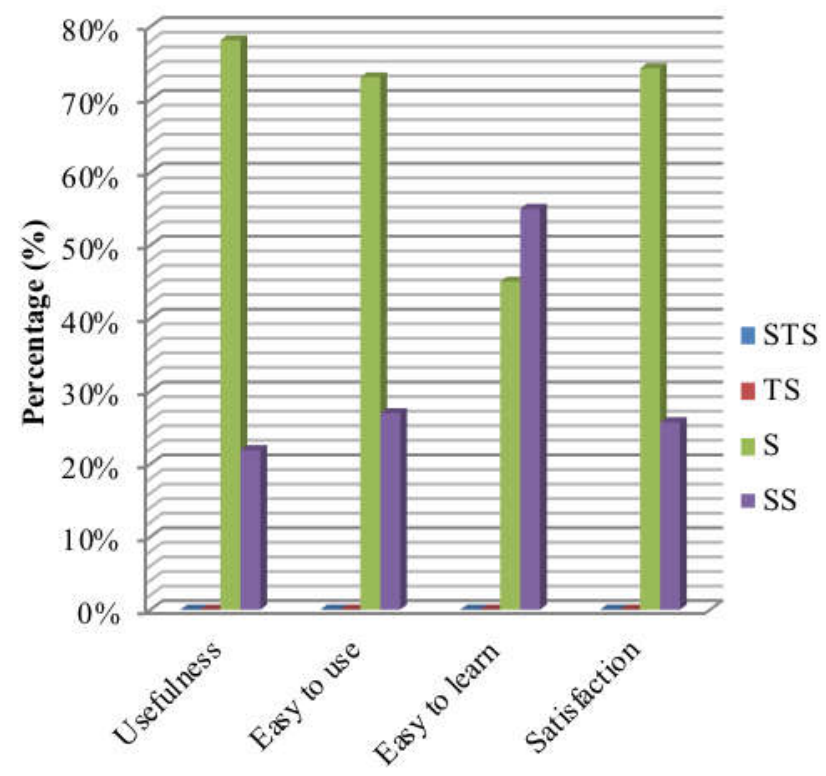

Figure 5. Student Response Chart
In Figure 5, Obtaining student response data related to the learning model using social media it used a usability poll known as USE Questionnaire [17]. The scale used is the Likert scale from 1 to 4; Where 1 (very disagrees) (STS), 2 disagrees (TS), 3 is concurring (ST), and 4 is very concurring (SS). The aspect measured by this poll includes the (usefulness), (ease of use), (ease of learning), and (satisfaction).

The development of blended learning is a studentoriented form of learning because in this method students play a very dominant role in the learning process, It can be seen in Figure 5, the student response results in the learning process assisted by students worksheet with blended learning by Edmodo expressed very agreed (SS) and agreed (ST). The results of Utami's research, et al, on the influence of Edmodo-based Blended Learning and Learning Motivation on the learning outcomes of Biology and Biology students' Retention in Human Blood Circulation in grade VII Middle School said that the Edmodo-based learning process students became interested, because of the interaction between the teacher and students in communication and collaborating on various content in the form of text, images, links, videos, and audio [18]. According to Krishnamurthy, Edmodo is an advantage and solution for researchers and teachers who are often disrupted by their learning activities because of a sudden agenda or schedule [19]. Next is the display of student worksheets using Edmodo, as shown in Figure 6.

Edmodo is an online platform to support teachers in learning activities and to improve creativity to involve students in collaborative learning and cognitive distribution. Edmodo presents opportunities for students to interact with fellow students and teachers in an academic environment. What is more, the use of Edmodo can educate students on how to behave online and be useful for organizing their learning activities with a safe system. Edmodo implements an environment with a characteristic of learning and teaching that can produce student excitement, students become more independent, without forgetting the standards of measuring student success. Edmodo is a safe learning platform for teachers, students and schools based on social media (Figure 6). Edmodo gives a regulated and secure way for classrooms to connect and collaborate, share content and access work, grades, and school notifications. Edmodo's purpose is to assist educators to harness the power of social media to tailor a class for each student. Edmodo can help educators build virtual classrooms based on real-life lessons at school, where there are 
assignments, quizzes, and classes at the end of each lesson [20].

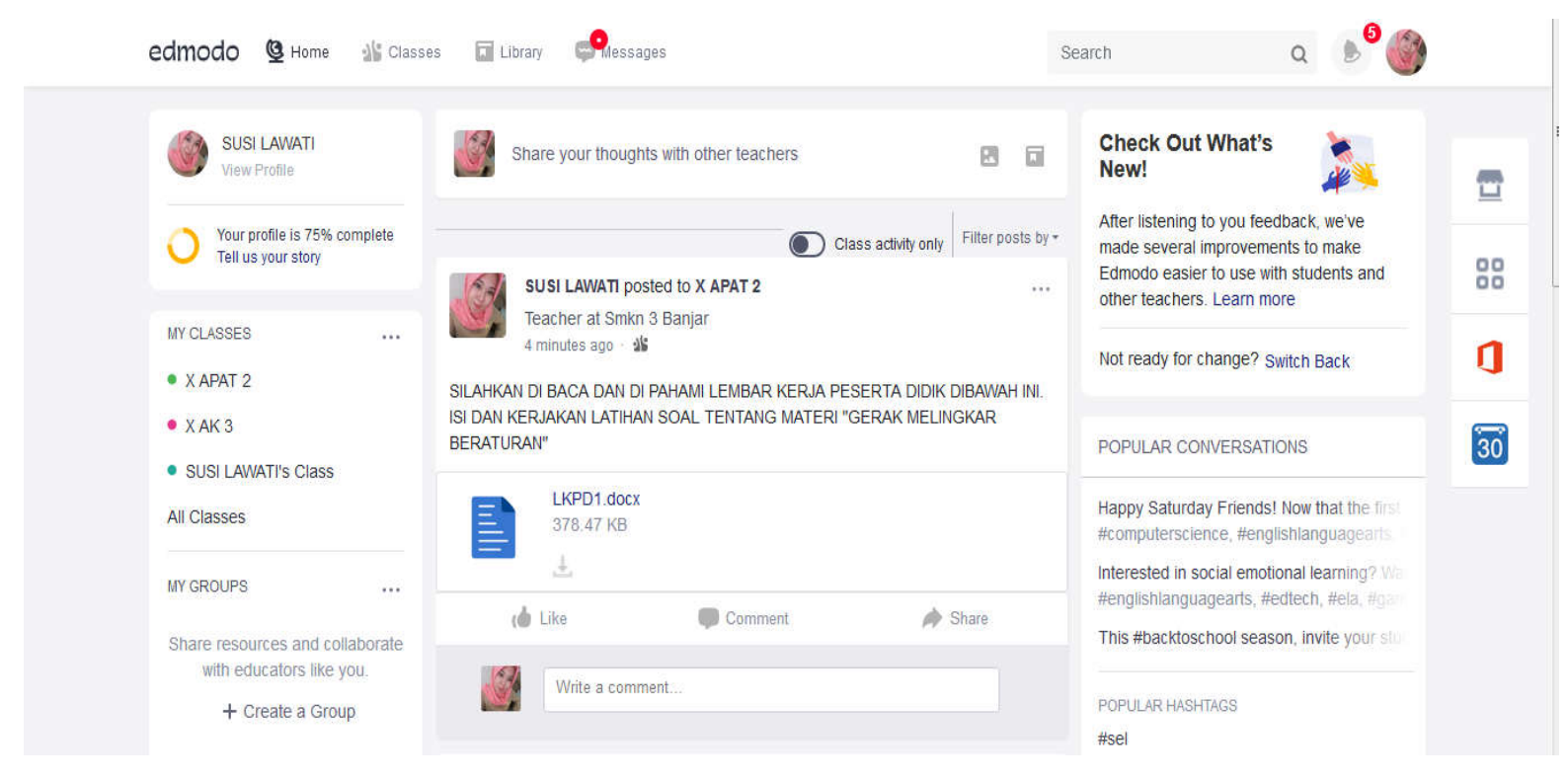

Figure 6. Edmodo display

Constraints in this study, researcher.s have not been able to connect parents into the virtual media Edmodo because not all parents have a smartphone, and difficulties for students on signal internet that is unstable and package quota to access Edmodo. As Yunita's research results, about the effectiveness of Edmodo-Assisted Problem Based Learning to Improve Physics Learning Achievement in Temperature and Heat of Class X Light Vehicle Engineering at Tunas Bangsa Wanareja Vocational School, stated that the deficiencies in learning problem Based Learning are disruptions to slower internet connections, and there is no choice for sending messages to fellow students, communication with students takes place in groups on Edmodo [21].

\section{Conclusion}

The students ' worksheets have been developed on the subject of circular motion with the Edmodo-based blended learning as the motivations of students based on the overall rate of the score at the entire question of $83.62 \%$ With students ' responses are worthy of learning media. The feasibility rate is $79.68 \%$ of material experts, and $77.27 \%$ of media experts. With the value of the score, this medium is categorized as viable and can motivate learners as a learning medium and can be used by learners in the physics learning process.

\section{Acknowledgement}

The author would like thanks to Head Department of Master in the Physics Education University of Ahmad Dahlan for support and assisted so the research can be completed.

\section{References}

[1] A. Prastowo, Pengembangan Bahan Ajar. Jakarta: Kencana, 2014.

[2] Ishafit and N. Fitriastuti, "Pengembangan Lembar Kerja Siswa (LKS) Berbasis Guided Inquiry Berbantuan Media Virtual Phet pada Materi Momentum dan Tumbukan untuk Meningkatkan Penguasaan Konsep Fisika Siswa Kelas XI," in Prosiding Seminar Nasional Quantum, 2016.

[3] M. M. Lombardi, "Authentic Learning for the 21st Century: An Overview,” ELI Pap. 1, 2007.

[4] J. . Rooney, "Blended Learning Opportunities to enhance educational programming and meetings," Assoc. Manage., vol. 55, no. 5, pp. 26-32, 2003.

[5] F. Gruber, "Edmodo: Microblogging for Education," http://www.somewhatfrank.com/2008/03/Edmodomicroblo.html, 2008.

[6] S. C. Kong and Y. Song, "The impact of a principlebased pedagogical design on inquiry-based learning in a seamless learning environment in Hong Kong," Educ. Technol. Soc., vol. 17, no. 2, pp. 127-141, 2014.

[7] Sulastri, "Pembelajaran Muatan Lokal Pendidikan Lingkungan Hidup dengan Model Pembelajaran Group Investigation untuk SMA/MA," J. Pendidik. Sains, vol. 2, no. 1, pp. 12-17, 2014.

[8] M. Driscoll, "Blended learning: Let's get beyond the hype," 2002.

[9] B. Basori, "Pemanfaatan Social Learning Network "Edmodo" Dalam Membantu Perkuliahan Teori Bodi 
Susilawati et al.

Otomotif Di Prodi Ptm Jptk Fkip Uns,” J. Ilm. Pendidik. Tek. dan Kejuru., vol. 6, no. 2, pp. 99-105, 2013.

[10] G. Suriadhi, I. D. K. Tastra, and I. W. Suwatra, "Pengembangan E-learning Berbasis Edmodo pada Mata Pelajaran IPA Kelas VIII di SMPN 2 Singaraja," J. Edutech Univ. Pendidik. Ganesha, vol. 2, no. 1, pp. $1-10,2014$.

[11] C. Peklaj and M. Puklek Levpušček, "Students' motivation and academic success in relation to the quality of individual and collaborative work during a course in educational psychology," in 31st Annual ATEE Conference, 2006, pp. 146-161.

[12] H. Douglas Brown, Teaching by Principles An Integrative Approach to Language Pedagogy. New York: White Plains, 2001.

[13] P. A. Tipler, "Fisika Untuk Sains dan Teknik Jilid I." Penerbit Erlangga, Jakarta., 2001.

[14] Sugiyono, Metode Penelitian Kuantitatif, Kualitatif dan $R \& D$. Bandung: Alfabeta, 2015.

[15] Mulyanta and M. Leong, Tutorial Pembangunan Multimedia Interaktif Media Pembelajaran. Yogyakarta: Universitas Atma Jaya Yogyakarta, 2009.

[16] A. Sujiono, Pengantar Statistik Pendidikan. Jakarta: Graha Grafindo Persada, 2011.

[17] A. M. Lund, "Measuring usability with the USE questionnaire," Usability Interface, vol. 8, no. 2, pp. 36, 2001.

[18] U. A. Daulay, Syarifuddin, and B. Manurung, "Pengaruh Blended Learning Berbasis Edmodo dan Motivasi Belajar Terhadap Hasil Belajar IPA Biologi dan Retensi Siswa pada Sistem Peredaran Darah Manusia di Kelas VIII SMP Negeri 5 Medan," $J$. Pendidik. Biol., vol. 6, no. 1, pp. 260-266, 2016.

[19] N. B. Krishnamuty, "Pengaruh Metode Penugasan Melalui Kelas Virtual Edmodo Terhadap Hasil Belajar Siswa Pada Konsep Jaringan Tumbuhan,” UIN Syarif Hidayatullah, 2015.

[20] Y. Ariani, Y. Helsa, S. Ahmad, and R. Prahmana, "Edmodo social learning network for elementary school mathematics learning," J. Phys. Conf. Ser., vol. 943, no. 1, p. 012056, Dec. 2017.

[21] L. Yunita, "Efektifitas Problem Based Learning Berbantuan Edmodo Untuk Meningkatkan Prestasi Belajar Fisika Studi Pada Suhu Dan Kalor Kelas X Teknik Kendaraan Ringan SMK Tunas Bangsa Wanareja," in Prosiding Seminar Nasional XI "Rekayasa Teknologi Industri dan Informasi 2016 Sekolah Tinggi Teknologi Nasional Yogyakarta," 2016, pp. 159-165.
Development Student Worksheet in the Topic of Regular Circular Motion With Blended Learning Based ... 